\title{
Development of Colon Targeting Tablet of a JAK Inhibitor to Combat Chronic Ulcerative Colitis: A Novel Approach for Local Drug Delivery
}

\author{
Vakar $^{1}$, Rupa Mazumder ${ }^{1, \star}$, Swarupanjali Padhi' ${ }^{1}$ Kirpa Shanker Tiwari², Parikh Kinjal ${ }^{3}$ \\ ${ }^{1}$ Department of Pharmaceutics, Noida Institute of Engineering and Technology (Pharmacy Institute), 19 Knowledge Park - II, \\ Institutional Area, Greater Noida, Uttar Pradesh, INDIA. \\ ${ }^{2}$ Sun Pharmaceutical Industries Limited, Sarhaul, Sector - 18, Gurugram, Haryana, INDIA. \\ ${ }^{3}$ Faculty of Pharmacy, The Maharaja Sayajirao University of Baroda, Kalabhavan, Vadodara, Gujarat, INDIA.
}

\begin{abstract}
Background: Tofacitinib, a pan-Janus kinase (JAK) inhibitor, initially used for the treatment of rheumatoid arthritis, was later found to have robust efficacy in Phase 2 and Phase 3 ulcerative colitis clinical trials. It had been approved by FDA for its use in the treatment of moderate to severe ulcerative colitis, in 2018. Objectives: The main objective of the present work was to develop a new colonic drug delivery system for tofacitinib using combined approaches of formulating an extended release matrix tablet along with a $\mathrm{pH}$ sensitive polymer coating of Eudragit ${ }^{\circledR}$ S100. Methods: The core tablets of tofacitinib were prepared by wet granulation method containing sodium carboxymethyl cellulose (CMC) as rate controlling polymer. Formulation variables used in the matrix system and $\mathrm{pH}$ dependent coating were optimized. Results: Negligible drug release was obtained in $0.1 \mathrm{~N} \mathrm{HCl}$ and $6.4 \mathrm{pH}$ phosphate buffer media, where as in $7.2 \mathrm{pH}$ phosphate buffer media, the drug release increased up to $94.2 \pm 2.0 \%$. Minimum concentration of sodium CMC was $11 \%(\mathrm{w} / \mathrm{w})$ to ensure $6 \mathrm{~h}$ 's extended release of drug from the matrix tablet. While, the minimum functional coating percentage, was found to be $13 \%$ in order to obtain an adequate lag time. Conclusion: The study showed that, the lag time of the drug release was highly affected by the coating percentage of Eudragit S 100 and product temperature during coating. After the lag time, extended drug release was observed, and rate of drug release was found to be depended on the concentrations of sodium CMC used in the core tablet. The final colon targeted formulation showed no change in either its physical appearance, drug content or in dissolution pattern even after three months of storage at $40 \pm 2{ }^{\circ} \mathrm{C} / 75 \pm 5 \% \mathrm{RH}$.
\end{abstract}

Key words: Colon targeted matrix tablet, Controlled release, Lag period, Ulcerative colitis, Tofacitinib, JAK inhibitor, Immunosuppressant.

\section{INTRODUCTION}

Ulcerative Colitis (UC) is a chronic idiopathic inflammatory bowel disease characterized by chronic gastrointestinal inflammation that can affect any part of colon, but commonly rectum. Moreover, sometimes the inflammation further extends towards the proximal part of colon in contiguous fashion. Bloody diarrhea, urgency and tenesmus are the most noticed symptoms of ulcerative colitis. The etiology of ulcerative colitis is complex; the exact reason of its cause is still not clear; however, it is contemplated to be associated with host epigenetic, genetic, dysregulation of immune system and other environmental factors. ${ }^{1-4}$ There has been a dramatic increase in inflammatory bowel diseases over the past several years and approximately one third of the patients of ulcerative colitis have to undergo operative treatments. If the patients of ulcerative colitis are not diagnosed and treated timely, the risk of development of colorectal cancer increases. $^{1-4}$
Submission Date: 26-08-2020; Revision Date: 08-10-2020; Accepted Date: 09-02-2021

DOI: 10.5530/ijper.55.2s.113 Correspondence: Dr. Rupa Mazumder Professor and Dean, Noida Institute of Engineering and Technology (Pharmacy Institute), 19 Knowledge Park - II, Institutional Area, Greater Noida-201306, Uttar Pradesh, INDIA. Phone no: +919871963644 Email id: rupa_mazumder@ rdifmail.com

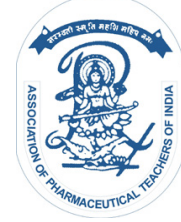

www.ijper.org 
Colon targeted drug delivery trough oral route is gaining high importance, because it is used either to treat the local diseases of colon such as ulcerative colitis, Crohn's disease, colorectal cancer and so on, or for the delivery of drugs that degrade in upper GIT, e.g., proteins and peptides. ${ }^{5}$ Various approaches have been used for colon targeted drug delivery through oral route, which include $\mathrm{pH}$, time, microbial degradation dependent drug deliveries, prodrug approaches and others. ${ }^{6}$ The problems associated with solely time or $\mathrm{pH}$ dependent drug delivery system are that sometime they show premature drug release or release of drug at inaccurate site(s) that can be overcome by using hybrid techniques. Combination of time dependent and $\mathrm{pH}$ dependent approaches can result in development of such a formulation that can prevent the drug release in upper gastrointestinal tract guaranteeing complete sustained drug release to colon after administrating matrix tablets through oral route. ${ }^{7}$ There are large numbers of polymers that can be used in the preparation of matrix tablets, such as sodium CMC, hydroxyl propyl methyl cellulose, and polyethylene glycol and many others. Selection of polymers depends on the physiochemical properties of the drug. ${ }^{8}$

Conventionally available treatments for ulcerative colitis use cyclosporine, 5-aminosalisalic acid, immunomodulators, glucocorticoids and mesalamine. These agents have been neither effective, nor safe, because some of these are associated with serious and toxic side effects like osteoporosis, muscle wasting, neuropsychiatric disorders and others. ${ }^{9}$ Other better options, such as tumor necrosis factor (TNF- $\alpha$ ) inhibitors, have high safety and long term efficacy data, but the main drawbacks established with these biologicals are loss of responses due to the formation of antibody and the high cost associated with long term therapy (add reference). Reportedly, 33\% patients are unable to respond to TNF blockers and another one third of the patients have been reported with loss of response over time. ${ }^{10,11}$ Consequently, a new, most efficient, long lasting and safe option is a need of the day for the treatment of ulcerative colitis which will target the Janus kinases (JAK) / signal transducer and transcription (JAK / STAT) signaling pathways. Thus, the oral application of the colon targeted drug delivery system containing the pan-JAK inhibitor, tofacitinib, will meet most of the criteria required so far to fulfill the requirement for effective treatment of UC. Tofacitinib has been approved by FDA in 2018 to treat moderate to severely active UC. In various clinical studies, patients suffering from moderate to severely active UC, have been treated with this small molecule, tofacitinib, as reported in the phase 2 clinical trials data by Sandborn et al. and Feagan. ${ }^{12,13}$
The objective of the research work was the development of colon targeted matrix tablet of tofacitinib intended for delivery of drug specifically to the colon, by appropriately combining the use of rate controlling polymer sodium $\mathrm{CMC}$ in core with a $\mathrm{pH}$ sensitive coating of Eudragit ${ }^{\circledR}$ S100 and to optimize the matrix formulation and process parameters of coating. The rate of drug release was controlled to reduce the dosing frequency, to prevent dose dumping and to demonstrate its site specificity. $\mathrm{pH}$ dependent solubility of tofacitinib led to variation in drug release in vivo from the conventional tofacitinib tablets, because the tablets moved throughout GIT having different $\mathrm{pH}$ segments and showed difference in release which cause fluctuations in drug absorption from the upper GIT. Thus, functional coating of the tablet was supposed resolve this problem by protecting the exposure of core tablet to different $\mathrm{pH}$ segments of the GIT. Site specific delivery of tofacitinib to the affected area would also improve the pharmacological and therapeutic responses. Tofacitinib had shown immunosuppressant activity upon systemic exposure; hence, various side effects were observed upon systemic exposure during clinical trials. However, the proposed novel formulation would provide localized colonic delivery of tofacitinib and thereby, would avoid systemic side effects.

\section{MATERIALS AND METHODS}

\section{Materials}

All the ingredients necessary for the study, namely, tofacitinib citrate, microcrystalline cellulose 101, lactose, hydroxypropyl cellulose-L, sodium carboxymethyl cellulose, magnesium stearate, Eudragit ${ }^{\circledR}$ S100, triethyl citrate, talc, isopropyl alcohol and simethicone USP $(100 \%)$ had been gifted by Sun Pharmaceutical Industries Limited, Gurugram, India, All other reagents and solvents used, were of analytical grades and pharmacopoeial standards. JMP-SAS ${ }^{\mathrm{TM}}$ version 14 was used for the design of experiments and data analysis.

\section{Methods}

\section{Preparation of calibration curve of tofacitinib citrate}

The stock solution $(100 \mu \mathrm{g} / \mathrm{mL})$ of tofacitinib citrate was prepared in $0.1 \mathrm{~N} \mathrm{HCl}$ and sonicated for $10 \mathrm{~min}$. Using the stock solution, serial dilutions of different concentrations were prepared to get 5, 10, 15, 20, 25 $\mu \mathrm{g} / \mathrm{mL}$ concentrations. The absorbance of prepared dilutions against blank was measured at $289 \mathrm{~nm}$ using UV spectrophotometer and to validate the data obtained, the preparation of the calibration curve was performed 
in triplicate. The same procedure was followed for preparation of calibration curves in $\mathrm{pH} 6.4$ and $\mathrm{pH} 7.2$ phosphate buffer solutions and in distilled water. The absorbance of prepared dilutions against blank was measured at $287 \mathrm{~nm}, 287 \mathrm{~nm}$ and $288 \mathrm{~nm}$ in $\mathrm{pH} 6.4$ phosphate buffer solution, pH 7.2 phosphate buffer solutions and distilled water, respectively. ${ }^{14}$

\section{Pre-formulation studies}

The following properties were evaluated during the preformulation studies:

\section{Physical characterization}

Physical properties of tofacitinib citrate were evaluated on its appearance, color, odor, melting point, solubility and drug identification.

\section{Drug and excipients compatibility study}

Physical compatibility of the drug with other excipients was tested in order to identify if there was any drugexcipients incompatibility. Drug alone and its physical mixture (1:1) were kept for a period of four weeks at three different condition, viz, $25 \pm 2^{\circ} \mathrm{C} / 60 \pm 5 \% \mathrm{RH}$, $40 \pm 2^{\circ} \mathrm{C} / 75 \pm 5 \% \mathrm{RH}$ open, $40 \pm 2^{\circ} \mathrm{C} / 75 \pm 5 \% \mathrm{RH}$ closed and observed for any change in the physical appearance. FTIR absorption spectra of pure drug and its physical mixture with other ingredients were taken at room temperature using $\mathrm{KBr}$ press pellet technique. Pellets were prepared by applying 5-7 tons pressure. IR spectra of tofacitinib citrate alone, tofacitinib citrate with sodium CMC and physical mixture of tofacitinib citrate with all other excipients were recorded using FTIR500 Fourier Transform Infrared Spectroscopy (Perkin Elmer, Japan). ${ }^{15}$

\section{Micromeritic properties of blends}

The following micromeritic properties were studied: ${ }^{16}$

\section{- Determination of bulk density}

Weighed quantity of the blend was transferred into a graduated cylinder to measure the volume occupied by the blend and then the bulk density of the blend was calculated using the following formula.

Bulk density $=$ Mass of powder $/$ Volume of powder

\section{- Determination of tapped density}

Tapped density of the blend was measured using USP type 1 apparatus. Weighed quantity of the blend was transferred into a graduated cylinder. The cylinder was fixed in tapped densitometer holder, tapped for 10, 500 and 1250 times and observed up to not more than $1 \mathrm{ml}$ difference after tapping 500 and 1250 times. The tapped volume was observed after 1250 tapping and calculated the tapped density using the following formula.

Tapped density $=$ Mass of powder $/$ Tapped volume

\section{- Carr's index}

Carr's index or compressibility index, measuring the tendency of a blend to be compressed, was calculated using the tapped density and bulk density values using the mentioned formula.

Carr's index $=[$ (tapped density-bulk density $) /$ tapped density] $\times 100$

\section{- Hausner's ratio}

Hausner's ratio is the ratio of tapped density to bulk density. It is the number that is correlated to the flow ability of a powder or granular material. It was calculated by the formula.

Hausner's ratio $=$ Tapped density / Bulk density

\section{- Angle of repose}

Angle of repose was determined by the funnel method. A funnel was fixed in a burette stand at $2.4 \mathrm{~cm}$ height from the base. Then the blend was poured onto the funnel and allowed to form a pile. Surface diameter and height of the heap were measured. The same procedure was repeated three times and the average of three observations was taken and placed in the given equation to calculate the angle of repose of the blend.

$\operatorname{Tan}(\alpha)=$ height $/ 0.5$ base

\section{Preparation and optimization of core tablets}

Controlled release matrix tablets of tofacitinib citrate were prepared according to the design generated by the software JMPTM version 14, using wet granulation method.

A full factorial design $2^{3}$ was used to study the quantitative aspects of the effects and relationships among various formulation variables of the core tablet. Design with a total of 8 experimental runs and 2 additional center points was selected to optimize the various formulation parameters at two levels (low and high, coded as -1 and +1 ) as shown in Table 1 . In this design microcrystalline cellulose (X1) used as disintegrate, hydroxyl propyl cellulose-L (X2) used as binder and sodium CMC (X3) used as release rate controlling polymer were taken as independent variables and their effect was studied on drug release (\%) at $1 \mathrm{~h}(\mathrm{Y} 1)$, at $3 \mathrm{~h}(\mathrm{Y} 2)$ and at $6 \mathrm{~h}(\mathrm{Y} 3)$ which were taken as dependent variables (Table 2). Batch F9 was considered as a center point with a reproducible batch F9 rep. The dissolution response of all the batches were statistically analyzed and obtained the composition of a final core batch, described in Table 16. 
All ingredients were weighed accurately and sifted separately through \#30 ASTM sieve. Tofacitinib citrate, microcrystalline cellulose and lactose were co-shifted through \#30 ASTM sieve and mixed for $10 \mathrm{~min}$. The mixed blends were granulated using binder solution of hydroxyl propyl cellulose (HPC). The prepared granules were dried at $60^{\circ} \mathrm{C}$ for $2 \mathrm{~h}$ in a hot air oven and checked for the moisture content to be not more than $1 \%$. These dried granules were passed through \#40 ASTM sieve to get uniform sizes and mixed with sodium carboxy methyl cellulose for $10 \mathrm{~min}$. Magnesium stearate was added to lubricate the blend and continue mixing for another 10 mins in the same poly bag. Flow properties of blend were determined prior to compression. Lubricated blends were compressed into tablets (Table 2) using Cadmach 16 station tablet press machine with $6 \mathrm{~mm}$ round concave punches. Weight variation, thickness, hardness, friability and in vitro dissolution studies were performed for the core tablets. Enteric coatings were performed on the optimized batch.

\section{Preparation of coating media}

Accurately weighed quantity of talc and Eudragit ${ }^{\circledR}$ S100 were shifted through ASTM 60\# sieve separately. Accurately weighed quantity of isopropyl alcohol (IPA) was collected in a stainless steel container and Eudragit ${ }^{\mathbb{R}}$ S100 was slowly added to it by continuously stirring and the dispersion was continuously stirred further for $1 \mathrm{hr}$. Talc was separately dispersed in water for $30 \mathrm{~min}$ in high speed colloidal mill to get a homogenous dispersion and

\begin{tabular}{|c|c|c|}
\multicolumn{3}{|c|}{ Table 1: Levels of Independent Variables for Core } \\
Tablet. \\
Independent Variable & High Level (+1) & Low Level (-1) \\
\hline X1 & 30 & 10 \\
\hline X2 & 4 & 0 \\
\hline X3 & 11 & 5 \\
\hline
\end{tabular}

then simethicone USP $(100 \%)$ was added in this dispersion to avoid foaming. The dispersion of talc was added to the dispersion of isopropyl alcohol under continuous stirring for about $30 \mathrm{~min}$, followed by the addition of triethyl citrate to it to stabilize the dispersion. The prepared dispersion was passed through ASTM 60\# sieve and the dispersion was kept under stirring at slow speed throughout the coating process.

\section{Enteric coating of core tablets}

Enteric coating was performed for the optimized matrix batch (f10) resulting from the design of experiment software. Coating was performed using Gansons coating machine by keeping inlet temperature at $35-40^{\circ} \mathrm{C}$, outlet temperature at $30-35^{\circ} \mathrm{C}$, bed temperature, $30^{\circ} \mathrm{C}$, pan RPM of 10 , atomization at 2 bar and spray rate of $10 \mathrm{~g} / \mathrm{min}$. Quantities of isopropyl alcohol and water were taken based on $10 \% \mathrm{w} / \mathrm{w}$ solid content of coating dispersion by keeping the ratio of IPA and water as 90:10. Coating was performed using the formula given in Table 3.

\section{Optimization of coating process parameters}

A $2^{2}$ design was used to study the effects and relationships among various coating process parameter variables of the coated tablets (Tables 4, 5). The two-level factorial designs were the simplest form of orthogonal design, commonly employed for screening and factor influence

Table 3: Composition of Coating Formula.

\begin{tabular}{|c|c|}
\hline Ingredients & Quantity (g) \\
\hline Isopropyl alcohol & 810 \\
\hline Water $^{\circledR}$ & 90 \\
\hline Eudragit $^{\circledR}$ S100 & 70 \\
\hline Triethyl citrate & 10 \\
\hline Talc & 20 \\
\hline
\end{tabular}

\begin{tabular}{|c|c|c|c|c|c|c|}
\hline Batch Code & $\begin{array}{l}\text { Tofacitinib Citrate } \\
\text { (mg) }\end{array}$ & $\begin{array}{l}\text { Lactose } \\
\text { (mg) }\end{array}$ & $\begin{array}{l}\text { Microcrystalline } \\
\text { Cellulose (mg) }\end{array}$ & $\begin{array}{l}\text { Hydroxy Propyl } \\
\text { Cellulose-L (mg) }\end{array}$ & $\begin{array}{l}\text { Sodium CMC } \\
(\mathrm{mg})\end{array}$ & $\begin{array}{c}\text { Magnesium } \\
\text { Stearate (mg) }\end{array}$ \\
\hline $\mathrm{F} 1$ & 16.25 & 66.75 & 10 & 0 & 5 & 2 \\
\hline $\mathrm{F} 2$ & 16.25 & 60.75 & 10 & 0 & 11 & 2 \\
\hline F3 & 16.25 & 46.75 & 30 & 0 & 5 & 2 \\
\hline F4 & 16.25 & 40.75 & 30 & 0 & 11 & 2 \\
\hline F5 & 16.25 & 62.75 & 10 & 4 & 5 & 2 \\
\hline $\mathrm{F} 6$ & 16.25 & 56.75 & 10 & 4 & 11 & 2 \\
\hline $\mathrm{F} 7$ & 16.25 & 42.75 & 30 & 4 & 5 & 2 \\
\hline F8 & 16.25 & 36.75 & 30 & 4 & 11 & 2 \\
\hline $\mathrm{Fg}^{*}$ & 16.25 & 51.75 & 20 & 2 & 8 & 2 \\
\hline F9*rep & 16.25 & 51.75 & 20 & 2 & 8 & 2 \\
\hline
\end{tabular}


studies. The $2^{2}$ design with a total of 4 experimental runs and 3 additional centre points was selected to optimize the various coating process parameters at two levels (low and high, coded as -1 and +1 ). In vitro drug release of all the batches were performed to study the impact of the process parameters on drug release and the final formulation for colon targeted drug delivery was selected on the basis of dissolution responses.

In this design product temperature (T) and \% weight build up (W) were taken as independent variables and their effects were studied on drug release (\%) at $1 \mathrm{~h}(\mathrm{Z1})$, $3 \mathrm{~h}(\mathrm{Z} 2)$ and $6 \mathrm{~h}(\mathrm{Z} 3)$, which were taken as dependent variables (Table 17).

\section{Post-compression studies}

The post compression studies on the prepared tablets included valuation of the following parameters:

\section{Shape and appearance}

Shape and appearance of the tablets were observed physically and color of the tablet was observed in sun light.

\section{Hardness}

Hardness of the tablets was tested using $8 \mathrm{M}$ bench top tablet hardness apparatus (Schlesinger ${ }^{\mathbb{P}}$ Pharmatron). The tablets were placed between two platens, one of which moved to apply sufficient force to the tablet to cause fracture. Loading occurred across the diameter of the tablets (sometimes referred to as diametric loading) and fracture occurred in that plane at a particular force applied, as was with conventional, round (circular crosssection) tablets; readings were recorded. The same procedure was followed for ten tablets from each batch and average values were calculated.

Table 4: Levels of Independent Variables of Coating Process Parameter.

\begin{tabular}{|c|c|c|}
\hline Independent Variable & Higher Level (+1) & Lower level (-1) \\
\hline Temperature & 32 & 28 \\
\hline Weight build up & 19 & 13 \\
\hline
\end{tabular}

\begin{tabular}{|c|c|c|}
\hline \multicolumn{3}{|c|}{ Table 5: Process Parameter Batches. } \\
\hline Batch Code & $\begin{array}{c}\text { Product Temperature } \\
\left({ }^{\circ} \mathrm{C}\right)\end{array}$ & \% Weight Build Up \\
\hline Coat f5 A & $32^{\circ} \mathrm{C}$ & $7 \%$ \\
\hline Coat f5 B & $32^{\circ} \mathrm{C}$ & $19 \%$ \\
\hline Coat f5 C & $28^{\circ} \mathrm{C}$ & $7 \%$ \\
\hline Coat f5 D & $28^{\circ} \mathrm{C}$ & $19 \%$ \\
\hline Coat f5 $\mathrm{E}^{\star}$ & $30^{\circ} \mathrm{C}$ & $13 \%$ \\
\hline Coat f5 $\mathrm{E}^{\star}$ rep1 & $30^{\circ} \mathrm{C}$ & $13 \%$ \\
\hline Coat f5E $\mathrm{E}^{\star}$ rep2 & $30^{\circ} \mathrm{C}$ & $13 \%$ \\
\hline
\end{tabular}

\section{Thickness}

Crown thickness of 10 tablets from each batch using Vernier caliper was determined and calculated the average thickness.

\section{Weight variation}

Individual weights of 20 tablets from each batch were measured using electronic weighing balance and average weights were calculated. Then individual tablet weights were compared with the average weight and finally, the standard deviations were calculated. According to IP / BP, pharmacopoeial percentage weight variation limit is $\pm 7.5 \%$ for $80-250 \mathrm{mg}$ tablet weights. ${ }^{17}$

\section{Friability}

Friability test was performed using Roche friabilator according to USP guidelines. Accurately weighed $6.5 \mathrm{~g}$ tablets were placed in the drum, it was rotated 100 times and then the tablets were collected. After removal of the loose dust, if any, the tablets were accurately reweighed and then friability was calculated in terms of $\%$ weight loss using the formula.

Friability $=[($ Initial weight-Final weight $) /$ Initial weight $]$ $\times 100$

In general, a maximum weight loss not more than $1 \%$ is acceptable. ${ }^{18}$

\section{Content uniformity}

Drug content uniformity was evaluated for each batch of tablets. From each batch, five tablets were weighed and powdered. Accurately weighed powder equivalent to $16.25 \mathrm{mg}$ tofacitinib citrate were taken in a $100 \mathrm{ml}$ volumetric flask, dissolved in $0.1 \mathrm{~N} \mathrm{HCl}$ and sonicated for $20 \mathrm{~min}$. Then the solution was filtered and aliquots of the filtrate were diluted and analyzed using UV spectrophotometer at $289 \mathrm{~nm}$ against the blank. The same procedure was repeated in triplicate and the average value was calculated. ${ }^{19}$

\section{In vitro dissolution studies}

In vitro dissolution study was performed using dissolution apparatus USP-Type 2 at $37 \pm 0.5^{\circ} \mathrm{C}$ with stirring rate of $100 \mathrm{rpm}$. To mimic the transition time from mouth to colon, dissolution for coated tablets was performed in sequential media, initially $2 \mathrm{~h}$ in $750 \mathrm{~mL}$ of $0.1 \mathrm{~N}$ $\mathrm{HCl}$, then for $1 \mathrm{~h}$ in $950 \mathrm{ml}$ of $\mathrm{pH} 6.4$ phosphate buffer (stage 1) and finally, for $6 \mathrm{~h}$ in $960 \mathrm{~mL}$ of $\mathrm{pH}$ 7.2 phosphate buffer (stage 2). $10 \mathrm{~mL}$ of aliquot was withdrawn at predetermined time point and replaced the volume with fresh media. The samples were analyzed at $289 \mathrm{~nm}$ in acidic media and $287 \mathrm{~nm}$ in basic media by a UV spectrophotometer (UV-1800 Shimadzu 
Spectrophotometer, Japan) and the amount of drug present in the samples were calculated. ${ }^{20}$

\section{Stability studies}

Stability studies were performed for the final formulation at $40 \pm 2^{\circ} \mathrm{C} / 75 \pm 5 \% \mathrm{RH}$ for 3 months and the tablets were evaluated for change in appearance, thickness, hardness, weight, assay and in vitro drug release.,21

\section{RESULTS AND DISCUSTION}

\section{Linear equations of calibration curve (Table 6)}

\section{Pre-formulation studies}

The pre-formulation studies included the evaluation of the following parameters:

\section{Physical characterization of drug}

The observed physical characteristics of the drug under study have been recorded in Table 7 .

\section{Drug identification}

UV spectra (Figure 1) of tofacitinib citrate showed the maximum absorbance at $289 \mathrm{~nm}$ which was in range with the USP specifications.

\section{Compatibility study}

In compatibility studies, no change was observed even after four weeks in the physical appearance. Drug interactions with other excipients were studied using FT-IR spectroscopy and no drug interaction was observed (Figures 2 and 3). From the interpretation data (Table 8) of the spectra obtained with the drug alone

\begin{tabular}{|c|c|c|c|}
\hline \multicolumn{4}{|c|}{ Table 6: Linear Equations in Different Media. } \\
\hline Sr. No. & Media & Linear Equations & R $^{2}$ Value \\
\hline 1 & Distilled water & $y=0.0298 x+0.0287$ & 0.9999 \\
\hline 2 & $0.1 \mathrm{~N} \mathrm{HCl}$ & $\mathrm{y}=0.0282 \mathrm{x}+0.0152$ & 0.9994 \\
\hline 3 & $\begin{array}{c}\mathrm{pH} 6.40 \\
\text { phosphate buffer }\end{array}$ & $\mathrm{y}=0.0348 \mathrm{x}-0.0264$ & 0.9959 \\
\hline 4 & $\begin{array}{c}\mathrm{pH} 7.20 \\
\text { phosphate buffer }\end{array}$ & $\mathrm{y}=0.0324 \mathrm{x}+0.0267$ & 0.9997 \\
\hline
\end{tabular}

\begin{tabular}{|c|c|c|}
\hline Description & \multicolumn{2}{|l|}{ Results } \\
\hline Appearance & \multicolumn{2}{|c|}{ White to off white powder } \\
\hline Odor & \multicolumn{2}{|l|}{ Odorless } \\
\hline Melting point & \multicolumn{2}{|c|}{$215 \pm 2^{\circ} \mathrm{C}$ obtained by capillary method } \\
\hline \multirow{4}{*}{$\begin{array}{l}\text { Solubility } \\
\qquad(n=3)\end{array}$} & $\mathrm{pH} 1.2 \mathrm{HCl}$ & $27.14 \mathrm{mg} / \mathrm{mL}$ \\
\hline & pH 6.4 phosphate buffer media & $0.2640 \mathrm{mg} / \mathrm{mL}$ \\
\hline & pH 7.2 phosphate buffer media & $0.2044 \mathrm{mg} / \mathrm{mL}$ \\
\hline & Water & $3.35 \mathrm{mg} / \mathrm{mL}$ \\
\hline
\end{tabular}

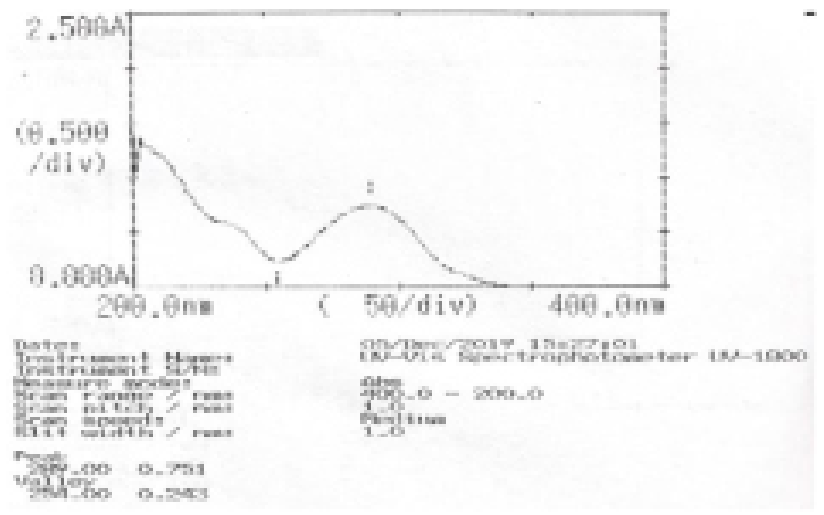

Figure 1: UV Spectra of Tofacitinib Citrate.

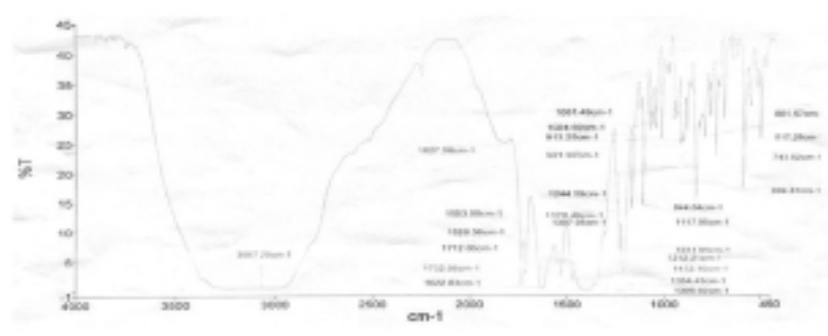

Figure 2: FT-IR Spectra of Tofacitinib Citrate.

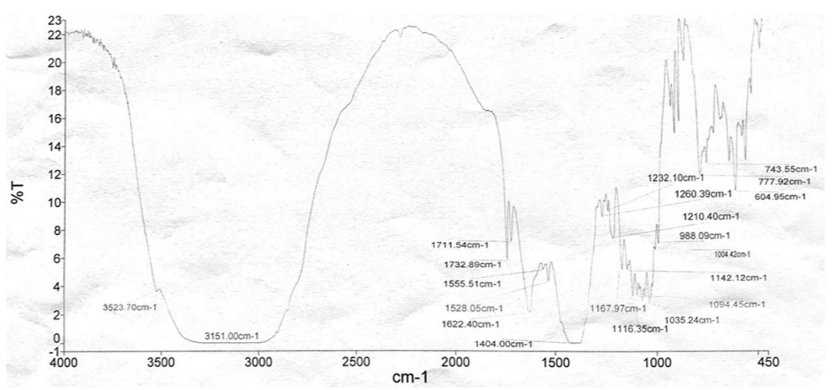

Figure 3: FT-IR Spectra of Physical Mixture of Tablet.

\section{Table 8: Interpretation of FT-IR Spectra of Tofacitinib} Citrate.

\begin{tabular}{|c|c|c|}
\hline $\begin{array}{c}\text { Sr. } \\
\text { No. }\end{array}$ & Functional Groups & $\begin{array}{c}\text { Wave No. } \\
\text { Observed(cm }\end{array}$ \\
\hline 1 & N-H Wagging (amines) & 913 \\
\hline 2 & O-H Bend (carboxylic acid) & 921 \\
\hline 3 & $=$ CH- Bend (alkenes) & 1081 \\
\hline 4 & C-N-Stretch (aliphatic amine) & 1244,1170 \\
\hline 5 & C-O-Stretch (alcohol, carboxylic acid) & 1307 \\
\hline 6 & C-H (rocking) & 1354,1395 \\
\hline 7 & C-H Bend & 1472 \\
\hline 8 & C=O-Stretch & 1712,1732 \\
\hline 9 & =CH-Stretch & 3057.29 \\
\hline 10 & C-N-Stretch (aromatic) & 1231 \\
\hline
\end{tabular}


and its physical mixture with other ingredients, it was observed that there was no major changes in frequencies of observed functional groups which indicated that there was no chemical interaction between the drug and excipients used in the formulations.

\section{Micromeritic properties of blends}

The micromeritic properties of the prepared blends have been depicted in Table 9. From the values of the Hausner's ratio and Carr's index it was concluded that all the blends were in fair flow ability range. The angle of repose of all the blends, except F2 and F4, indicated good flow properties.

\section{Post-compression studies}

\section{Shape and appearance}

The prepared core tablets were white colored, circular in shape and with plane concave surfaces.

\section{Table 9: Micrometric Properties of Prepared Blends.}

\begin{tabular}{|c|c|c|c|c|c|}
\hline $\begin{array}{c}\text { Batch } \\
\text { Code }\end{array}$ & $\begin{array}{c}\text { Bulk } \\
\text { Density } \\
(\mathbf{g} / \mathbf{m L})\end{array}$ & $\begin{array}{c}\text { Tapped } \\
\text { Density } \\
(\mathbf{g} / \mathbf{m L})\end{array}$ & $\begin{array}{c}\text { Hausner's } \\
\text { Ratio }\end{array}$ & $\begin{array}{c}\text { Carr's } \\
\text { Index } \\
(\%)\end{array}$ & $\begin{array}{c}\text { Angle of } \\
\text { Repose } \\
(\varnothing)\end{array}$ \\
\hline F1 & 0.666 & 0.800 & 1.201 & 16.75 & $34.2 \pm 0.95$ \\
\hline F2 & 0.655 & 0.816 & 1.245 & 19.73 & $36.1 \pm 0.96$ \\
\hline F3 & 0.677 & 0.833 & 1.230 & 18.72 & $34.6 \pm 0.92$ \\
\hline F4 & 0.689 & 0.833 & 1.208 & 17.28 & $35.2 \pm 1.01$ \\
\hline F5 & 0.666 & 0.800 & 1.201 & 16.75 & $32.8 \pm 1.24$ \\
\hline F6 & 0.666 & 0.816 & 1.225 & 18.38 & $34.6 \pm 0.70$ \\
\hline F7 & 0.689 & 0.833 & 1.209 & 17.28 & $33.3 \pm 0.75$ \\
\hline F8 & 0.689 & 0.851 & 1.235 & 19.03 & $35.0 \pm 0.90$ \\
\hline F9* & 0.666 & 0.816 & 1.225 & 18.38 & $33.4 \pm 0.93$ \\
\hline F9*rep & 0.666 & 0.816 & 1.225 & 18.38 & $33.4 \pm 0.92$ \\
\hline F10 & 0.654 & 0.798 & 1.220 & 18.04 & $34.5 \pm 0.91$ \\
\hline
\end{tabular}

\section{Evaluation of core tablets}

The readings of the various evaluated parameters of the prepared core tablets are recorded in Table 10.

\section{In vitro drug release and optimization of core tablets}

Drug released from the core tablets was evaluated in basic media using USP-II apparatus at $37 \pm 0.5^{\circ} \mathrm{C}$ with stirring rate of 100 RPM. $10 \mathrm{ml}$ aliquots were taken at predetermined time point and replaced the volume with the same media to avoid calculation errors. Samples were filtered and analyzed by UV spectrophotometer at $287 \mathrm{~nm}$. Batches F1 to F10 were evaluated in which batch F9 and F9 reproducible was considered as center point. F10 was formulated considering the composition suggested by the JMP software, as mentioned in Table 16. Effects of selected factors on drug release at the end of $1 \mathrm{~h}, 3 \mathrm{~h}$ and $6 \mathrm{~h}$ were visible from the variations in $\% \mathrm{DR}$ obtained at different levels of individual factor and combination of factors. The $\% \mathrm{DR}$ varied from 17.3 to $73.0 \%$ after1 h, 47.5 to $96.8 \%$ after $3 \mathrm{~h}$ and 85.6 to $96.4 \%$ after $6 \mathrm{~h}$ (Table 11$)$.

Obtained data of dependent variables were subjected to multiple regression analysis using JMP SAS software. The equation 1 (mathematical model) obtained for $\% \mathrm{DR}$ at $1 \mathrm{~h}$ is summarized below:

$\mathrm{Y} 1=86.280833333+-1.3815 \cdot \mathrm{X} 1+0.39125 \cdot \mathrm{X} 2+(\mathrm{X} 1-2) \cdot$ $\{(\mathrm{X} 2-20) \cdot 0.039375\}+-6.829166667 \cdot \mathrm{X} 3+(\mathrm{X} 1-2) \cdot\{(\mathrm{X} 3-8) \cdot$ $0.5895833333\}+(\mathrm{X} 2-20) \cdot\{(\mathrm{X} 3-8) \cdot-0.137916667\}+$ $(\mathrm{X} 1-2) \cdot\{(\mathrm{X} 2-20) \cdot\{(\mathrm{X} 3-8) \cdot-0.00520833)\}$.

The equation 2 (mathematical model) obtained for $\% \mathrm{DR}$ at $3 \mathrm{~h}$ is summarized below:

\begin{tabular}{|c|c|c|c|c|c|}
\hline Batch Code & Thickness ${ }^{*}(\mathrm{~mm})$ & $\begin{array}{l}\text { Weight Variation }{ }^{\S} \\
\text { (mg) }\end{array}$ & Hardness" (Kp) & $\begin{array}{c}\text { Content } \\
\text { Uniformity }{ }^{\Phi}(\%)\end{array}$ & Friability (\%) \\
\hline F1 & $3.17 \pm 0.017$ & $100.08 \pm 0.53$ & $4.04 \pm 0.017$ & $98.8 \pm 1.13$ & 0.90 \\
\hline $\mathrm{F} 2$ & $3.21 \pm 0.024$ & $100.46 \pm 0.75$ & $4.25 \pm 0.24$ & $99.1 \pm 1.10$ & 0.92 \\
\hline F3 & $3.22 \pm 0.023$ & $99.92 \pm 0.78$ & $4.40 \pm 0.15$ & $98.0 \pm 1.60$ & 0.92 \\
\hline F4 & $3.24 \pm 0.044$ & $100.49 \pm 0.37$ & $4.45 \pm 0.18$ & $98.6 \pm 1.36$ & 0.91 \\
\hline F5 & $3.17 \pm 0.018$ & $99.71 \pm 0.42$ & $4.15 \pm 0.10$ & $98.5 \pm 1.25$ & 0.90 \\
\hline F6 & $3.24 \pm 0.014$ & $100.29 \pm 0.27$ & $4.58 \pm 0.11$ & $99.7 \pm 1.20$ & 0.92 \\
\hline F7 & $3.20 \pm 0.020$ & $99.27 \pm 0.42$ & $4.43 \pm 0.21$ & $98.0 \pm 1.34$ & 0.76 \\
\hline F8 & $3.24 \pm 0.014$ & $100.48 \pm 0.83$ & $4.51 \pm 0.22$ & $99.9 \pm 1.40$ & 0.75 \\
\hline F9* & $3.24 \pm 0.018$ & $99.94 \pm 0.71$ & $4.50 \pm 0.23$ & $99.2 \pm 1.12$ & 0.62 \\
\hline F9*rep & $3.24 \pm 0.016$ & $99.99 \pm 0.21$ & $4.48 \pm 0.15$ & $99.7 \pm 1.15$ & 0.63 \\
\hline F10 & $3.21 \pm 0.037$ & $100.04 \pm 0.58$ & $4.33 \pm 0.18$ & $99.0 \pm 1.50$ & 0.76 \\
\hline
\end{tabular}

(All values represent mean $\pm S D,{ }^{5} n=20,{ }^{*} n=6,{ }^{\circledR} n=3$ ) 
$\mathrm{Y} 2=125.71833333+0.2625 \cdot \mathrm{X} 1+0.185 \cdot \mathrm{X} 2+(\mathrm{X} 1-2) \cdot$ $\{(\mathrm{X} 2-20) \cdot-0.0025\}+-7.166666667 \cdot \mathrm{X} 3+(\mathrm{X} 1-2) \cdot$ $\{(\mathrm{X} 3-8) \cdot-0.00833333\}+(\mathrm{X} 2-20) \cdot\{(\mathrm{X} 3-8) \cdot$ $0.0508333333\}+\left(X_{1}-2\right) \cdot\left\{\left(X_{2}-20\right) \cdot\right.$ $\{(\mathrm{X} 3-8) \cdot 0.0195833333)\}$.

The equation 3 (mathematical model) obtained for $\% \mathrm{DR}$ at $6 \mathrm{~h}$ is summarized below:

$\mathrm{Y} 3=98.212+-0.46875 \cdot \mathrm{X} 1+\quad 0.04125 \cdot \mathrm{X} 2+\quad(\mathrm{X} 1-2) \cdot$ $\{(\mathrm{X} 2-20) \cdot-0.060625\}+-0.9125 \cdot \mathrm{X} 3+(\mathrm{X} 1-20) \cdot\{(\mathrm{X} 3-8) \cdot$ $-0.09375\}+(\mathrm{X} 2-20) \cdot\{(\mathrm{X} 3-8) \cdot-0.01625\}+(\mathrm{X} 1-2) \cdot$ $\{(\mathrm{X} 2-20) \cdot\{(\mathrm{X} 3-8) \cdot 0.021875)\}$.

From the equations, it is clearly evident that sodium CMC is controlling the drug release (as evident by coefficient value of -6.82916667), whereas, MCC is increasing the drug release (co-efficient $=+0.39125)$, as observed at end of $1 \mathrm{~h}$, where, HPC-L = X1, MCC = X2, sodium $\mathrm{CMC}=\mathrm{X} 3$ and $\mathrm{Y} 1, \mathrm{Y} 2$ and $\mathrm{Y} 3$ represent dissolution responses after 1,3 and $6 \mathrm{~h}$, respectively.

As evident from Tables 12-15 and equations 1, 2 and 3 , the interaction terms (X1X2, X1X3, X2X3) between the two variables are statistically not significant $(p>0.05)$.
Similarly, as observed the $p$ values are $0.0380,0.0079$, 0.0338 , respectively $(\phi<0.05)$ for sodium CMC, indicating that it provides statistically significant difference for the model developed for drug release at the end of $1 \mathrm{~h}, 3 \mathrm{~h}$ and $6 \mathrm{~h}$.

Formulations having higher concentrations of sodium CMC in matrix showed more retardation of drug release in comparison to less concentration of sodium CMC. Although f2, f4, f6, f8 and f10 formulations had shown extended drug release, however, only the formulation f10 showed drug release in extended period over $6 \mathrm{~h}$, less than $50 \%$ drug release after $3 \mathrm{~h}$ and comparatively maximum drug release after $6 \mathrm{~h}$. Thus, batch f10 (composition shown in Table 16) was considered as the optimum batch for enteric coating.

From Figure 4, it is evident that $\mathrm{R}^{2}$ values for the selected model at 1,3 and $6 \mathrm{~h}$ are $0.93,0.98$ and 0.96 , respectively. The results of the statistical analysis suggest close correlation between actual and predicted values. The $R^{2}$ values indicate how close the data are fitted to the regression lines. Here, $R^{2}$ value indicates a better fit. However, RMSE values observed are 11.625, 5.4449 and

\begin{tabular}{|c|c|c|c|c|c|c|}
\hline \multirow{2}{*}{ Batch Code } & \multicolumn{7}{|c|}{ \% Drugle 11: Drug Release from Core Tablets. } \\
\cline { 2 - 7 } & $\mathbf{1 ~ h}$ & $\mathbf{2} \mathbf{h}$ & $\mathbf{3} \mathbf{h 3 h r s}$ & $\mathbf{4} \mathbf{h 4 h r s}$ & $\mathbf{5} \mathbf{h 5 h r s}$ & $\mathbf{6} \mathbf{h 6 h r s}$ \\
\hline F1 & $59.1 \pm 4.4$ & $92.1 \pm 3.1$ & $93.2 \pm 1.1$ & $92.8 \pm 0.1$ & $91.5 \pm 0.5$ & $91.5 \pm 2.2$ \\
\hline F2 & $18.7 \pm 0.4$ & $27.6 \pm 4.6$ & $49.6 \pm 8.5$ & $65.0 \pm 12.2$ & $80.5 \pm 14.5$ & $88.8 \pm 4.3$ \\
\hline F3 & $73.0 \pm 2.6$ & $90.6 \pm 3.6$ & $96.3 \pm 1.6$ & $96.4 \pm 2.1$ & $95.6 \pm 1.1$ & $96.4 \pm 1.8$ \\
\hline F4 & $17.3 \pm 1.5$ & $38.5 \pm 5.0$ & $54.1 \pm 3.1$ & $71.9 \pm 6.7$ & $85.2 \pm 4.2$ & $90.4 \pm 1.9$ \\
\hline F5 & $44.3 \pm 1.8$ & $92.0 \pm 2.0$ & $96.8 \pm 2.2$ & $95.6 \pm 1.6$ & $95.0 \pm 1.7$ & $95.8 \pm 0.9$ \\
\hline F6 & $19.3 \pm 3.1$ & $33.2 \pm 9.5$ & $48.3 \pm 11.0$ & $63.8 \pm 14.0$ & $79.0 \pm 9.5$ & $85.6 \pm 7.1$ \\
\hline F7 & $62.6 \pm 0.4$ & $87.0 \pm 11.9$ & $95.0 \pm 3.0$ & $92.7 \pm 12.2$ & $96.5 \pm 1.1$ & $90.6 \pm 10.5$ \\
\hline F8 & $19.8 \pm 0.5$ & $39.2 \pm 6.2$ & $57.3 \pm 9$ & $73.8 \pm 11.2$ & $84.4 \pm 9.6$ & $87.6 \pm 8.0$ \\
\hline F9* & $24.3 \pm 0.3$ & $38.2 \pm 7.8$ & $67.4 \pm 7.4$ & $83.5 \pm 5.3$ & $89.4 \pm 1.6$ & $89.2 \pm 1.7$ \\
\hline F9*rep & $28.7 \pm 4.0$ & $49.5 \pm 9.5$ & $68.1 \pm 11.4$ & $82.4 \pm 8.3$ & $90.9 \pm 3.9$ & $92.1 \pm 2.4$ \\
\hline F10 & $20.5 \pm 0.5$ & $33.5 \pm 3.1$ & $47.5 \pm 9.2$ & $75.5 \pm 6.2$ & $87.3 \pm 2.4$ & $89.9 \pm 0.5$ \\
\hline
\end{tabular}

(All values are expressed as mean $\pm S D$ )

\begin{tabular}{|c|c|c|c|c|c|c|}
\hline Responses & Sources & $\begin{array}{l}\text { Degree of } \\
\text { Freedom }\end{array}$ & $\begin{array}{l}\text { Sum of } \\
\text { Squares }\end{array}$ & Mean Square & F Ratio & Prob $>F$ \\
\hline $\mathrm{Y} 1$ (\% drug release $1 \mathrm{~h}$ ) & $\begin{array}{c}\text { Model } \\
\text { Error } \\
\text { Corrected total }\end{array}$ & $\begin{array}{l}7 \\
2 \\
9\end{array}$ & $\begin{array}{c}3784.2188 \\
270.2902 \\
4054.5090\end{array}$ & $\begin{array}{l}540.603 \\
135.145\end{array}$ & 4.0002 & 0.2145 \\
\hline Y2 (\% drug release $3 \mathrm{~h}$ ) & $\begin{array}{c}\text { Model } \\
\text { Error } \\
\text { Corrected total }\end{array}$ & $\begin{array}{l}6 \\
3 \\
9\end{array}$ & $\begin{array}{c}3746.2300 \\
70.3390 \\
3816.5690\end{array}$ & $\begin{array}{c}624.372 \\
23.446\end{array}$ & 26.6298 & 0.0107 \\
\hline Y3 (\% drug release $6 \mathrm{~h}$ ) & $\begin{array}{c}\text { Model } \\
\text { Error } \\
\text { Corrected total }\end{array}$ & $\begin{array}{l}7 \\
2 \\
9\end{array}$ & $\begin{array}{c}98.31875 \\
4.26125 \\
102.58000\end{array}$ & $\begin{array}{c}14.0455 \\
2.1306\end{array}$ & 6.5922 & 0.1380 \\
\hline
\end{tabular}




\begin{tabular}{|c|c|c|c|c|}
\hline \multicolumn{5}{|c|}{ Table 13: Parameter Estimates after 1 $\mathbf{h}$ for Core Tablet. } \\
\hline Term & Estimate & Std. Error & t Ratio & Prob>|t| \\
\hline Intercept & 86.280833 & 14.76852 & 5.84 & $0.0281^{*}$ \\
\hline HPC-L & -1.38125 & 2.055063 & -0.67 & 0.5708 \\
\hline MCC & 0.39125 & 0.411013 & 0.95 & 0.4416 \\
\hline$($ HPC-L-2)*(MCC-20) & 0.039375 & 0.205506 & 0.19 & 0.8657 \\
\hline Sod. CMC & -6.829167 & 1.370042 & -4.98 & $0.0380^{*}$ \\
\hline$(H P C-L-2)^{*}($ Sod. CMC-8) & 0.5895833 & 0.685021 & 0.86 & 0.4801 \\
\hline$($ MCC-20)*(Sod. CMC-8) & -0.137917 & 0.137004 & -1.01 & 0.4201 \\
\hline$(H P C-L-2)^{*}(M C C-20)^{*}($ Sod. CMC-8) & -0.005208 & 0.068502 & -0.08 & 0.9463 \\
\hline
\end{tabular}

\begin{tabular}{|c|c|c|c|c|}
\hline \multicolumn{2}{|c|}{ Table 14: Parameter Estimates after 3 $\boldsymbol{h}$ for Core Table. } \\
\hline Term & Estimate & Std. Error & t Ratio & Prob $>|\mathbf{t}|$ \\
\hline Intercept & 125.71833 & 6.91715 & 18.17 & $0.0030^{*}$ \\
\hline HPC-L & 0.2625 & 0.962532 & 0.27 & 0.8106 \\
\hline MCC & 0.185 & 0.192506 & 0.96 & 0.4380 \\
\hline$($ HPC-L-2)*(MCC-20) & -0.0025 & 0.096253 & -0.03 & 0.9816 \\
\hline Sod. CMC & -7.166667 & 0.641688 & -11.17 & $0.0079^{*}$ \\
\hline$($ HPC-L-2)*(Sod. CMC-8) & -0.008333 & 0.320844 & -0.03 & 0.9816 \\
\hline$\left(\right.$ MCC-20) ${ }^{*}($ Sod. CMC-8) & 0.0508333 & 0.064169 & 0.79 & 0.5113 \\
\hline$(\text { HPC-L-2 })^{*}(M C C-20)^{*}($ Sod. CMC-8) & 0.0195833 & 0.032084 & 0.61 & 0.6037 \\
\hline
\end{tabular}

\begin{tabular}{|c|c|c|c|c|}
\hline \multicolumn{5}{|c|}{ Table 15: Parameter Estimates after $\mathbf{6}$ h for Core Table. } \\
\hline Term & Estimate & Std. Error & t Ratio & Prob $>|\mathbf{t}|$ \\
\hline Intercept & 98.2125 & 1.854344 & 52.96 & $0.0004^{*}$ \\
\hline HPC-L & -0.46875 & 0.258035 & -1.82 & 0.2109 \\
\hline MCC & 0.04125 & 0.051607 & 0.80 & 0.5080 \\
\hline$($ HPC-L-2)*(MCC-20) & -0.060625 & 0.025803 & -2.35 & 0.1432 \\
\hline Sod. CMC & -0.9125 & 0.172023 & -5.30 & $0.0338^{*}$ \\
\hline$\left(\right.$ HPC-L-2) ${ }^{*}($ Sod. CMC-8) & -0.09375 & 0.086012 & -1.09 & 0.3895 \\
\hline$(M C C-20)^{*}($ Sod. CMC-8) & 0.01625 & 0.017202 & 0.94 & 0.4446 \\
\hline$(H P C-L-2)^{*}(M C C-20)^{*}($ Sod. CMC-8) & 0.021875 & 0.008601 & 2.54 & 0.1260 \\
\hline
\end{tabular}

1.4597, at three time points. Considering the $\mathrm{P}$ value, the model is found to be insignificant $(p>0.05)$ for effect of factors selected on drug release at the end of 1 and $6 \mathrm{~h}$. However, borderline significant effects have been observed at the end of $3 \mathrm{~h}$.

The composite desirability of 0.3742 had been obtained which predicted $37.2 \%$ chance of getting desired response using optimized values of factors (Figure 5). However, this was only for the core tablets and the prepared core tablets were also coated using functional coating which also impacted on desirability. Thus, the selected formulation fitted in the model after coating, as it produced drug release according to the desired release pattern. Selected pattern for core tablet showed 10-30\% drug release in $1 \mathrm{~h}, 35-55 \%$ drug release in $3 \mathrm{~h}$ and not less than $80 \%$ drug release in $6 \mathrm{~h}$.

As per the design of experiment, the core tablet composition was optimized and the final batch was prepared with the given concentrations (Table 16).

\section{In vitro drug release from coating process parameters batches}

Drug release from the coating process parameter batches have been mentioned below in Table 17. 
Assuming negligible drug release in $0.1 \mathrm{~N} \mathrm{HCl}$ and in pH 6.4 phosphate buffer stage 1, the effect of selected factors on drug release at the end of $1 \mathrm{~h}, 3 \mathrm{~h}$ and $6 \mathrm{~h}$, in $\mathrm{pH} 7.2$ phosphate buffer stage 2, was visible from the variation in $\%$ drug release obtained at different levels of individual factor and combination of factors.
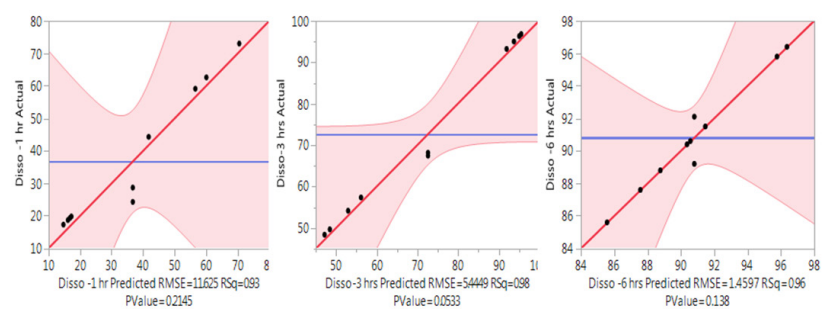

Figure 4: Dissolution Response Actual by Predictable Plots.

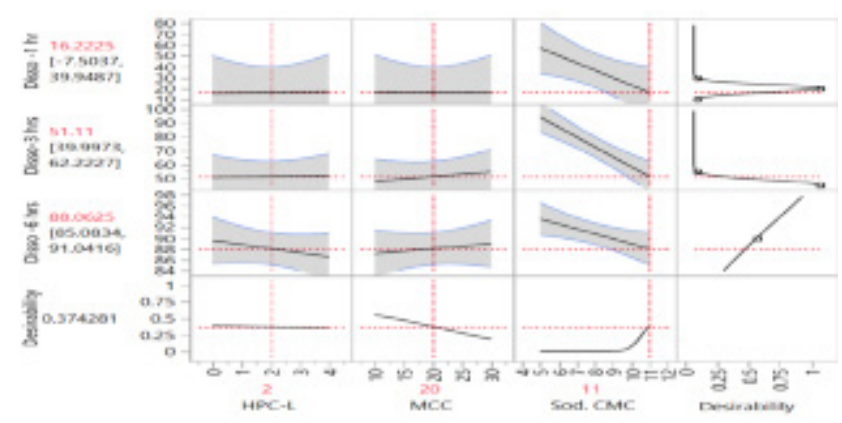

Figure 5: Prediction Profiler for Core Tablets.

\begin{tabular}{|c|c|c|}
\hline \multicolumn{3}{|c|}{ Table 16: Composition of F10 Batch. } \\
\hline Sr. No. & Ingredients & Quantity $(\mathbf{m g})$ \\
\hline 1 & Tofacitinib citrate & 16.25 \\
\hline 2 & Lactose & 48.75 \\
\hline 3 & Microcryatalline cellulose & 20 \\
\hline 4 & Hydroxy propyl cellulose-L & 2 \\
\hline 5 & Sodium CMC & 11 \\
\hline 6 & Magnesium stearate & 2 \\
\hline
\end{tabular}

Obtained data of dependent variables were subjected to multiple regression analysis using JMP SAS software. The equation, Z1 (mathematical model), obtained for $\%$ drug release at $1 \mathrm{~h}$ is summarized below:

$\mathrm{Z} 1=5.8+0.15 \cdot \mathrm{T}+-0.5 \cdot \mathrm{W}+(\mathrm{T}-30) \cdot\{(\mathrm{W}-13) \cdot-0.045833333\}$.

The equation, Z2 (mathematical model), obtained for $\%$ drug release at $3 \mathrm{~h}$ is summarized below:

$\mathrm{Z} 2=36.389285714+1.825 \cdot \mathrm{T}+-4.125 \cdot \mathrm{W}+$ $(\mathrm{T}-30) \cdot\{(\mathrm{W}-13) \cdot-0.120833333\}$.

The equation, Z3 (mathematical model), obtained for $\%$ drug release at $6 \mathrm{~h}$ is summarized below:

$\mathrm{Z} 3=94.366666676+0.15 \cdot \mathrm{T}+-0.466666667 \cdot \mathrm{W}+(\mathrm{T}-30) \cdot$ $\{(\mathrm{W}-13) \cdot 0.0625)$

From the equations Z1, Z2 and Z3, it is clearly evident that percentage weights built-up are controlling the drug release (as evident by the coefficient values of -0.5 , -4.125 and -0.466666667$)$ at the end of $1 \mathrm{~h}, 3 \mathrm{~h}$ and $6 \mathrm{~h}$ respectively, whereas product temperature is increasing the drug release (co-efficient $=+0.15,+1.825$ and +0.15 ), as observed at the end of $1 \mathrm{~h}, 3 \mathrm{~h}$ and $6 \mathrm{~h}$, respectively. As evident from the Tables 18-21 and equations Z1, Z2 and $\mathrm{Z3}$, the interaction terms (WT) between the two variables are statistically not significant $(p>0.05)$. Similar to, as observed in Table 19, 20 the $p$ value for weight build up, at the end of $1 \mathrm{~h}$, indicating that it provides nearly statistically significant difference and at the end of $3 \mathrm{~h}$ indicating that it provides statistically significant difference for the model developed for drug release at the end of $3 \mathrm{~h}$.

From Figure 6, it is evident that $R^{2}$ value for the selected model is $0.77,0.88$ and 0.45 at 1,2 and $3 \mathrm{~h}$. The results of the statistical analysis suggest close correlation between the actual and predicted values at the end of

\begin{tabular}{|c|c|c|c|c|c|c|c|c|}
\hline \multirow[b]{2}{*}{ Dissolution Media } & \multirow{2}{*}{$\begin{array}{c}\text { Time } \\
\text { (hr) }\end{array}$} & \multicolumn{7}{|c|}{$\%$ Drug Release from the Coated Tablets } \\
\hline & & Coat f5 A & Coat f5 B & Coat f5 C & Coat f5 D & Coat f5 $E^{*}$ & $\begin{array}{l}\text { Coat f5 } \\
\text { E*rep1 }\end{array}$ & $\begin{array}{l}\text { Coat f5 } \\
E^{\star} \text { rep2 }\end{array}$ \\
\hline \multirow{2}{*}{$0.1 \mathrm{~N} \mathrm{HCl}$} & 0 & $0.00 \pm 0.0$ & $0.00 \pm 0.0$ & $0.00 \pm 0.0$ & $0.00 \pm 0.0$ & $0.00 \pm 0.0$ & $0.00 \pm 0.0$ & $0.00 \pm 0.0$ \\
\hline & 2 & $0.4 \pm 0.5$ & $0.2 \pm 0.1$ & $1.4 \pm 0.7$ & $0.4 \pm 0.2$ & $0.3 \pm 0.3$ & $2.6 \pm 0.1$ & $0.2 \pm 0.1$ \\
\hline PB pH 6.4 Stage-1 & 3 & $1.9 \pm 0.4$ & $0.4 \pm 0.3$ & $2.0 \pm 0.4$ & $0.2 \pm 0.1$ & $0.1 \pm 0.1$ & $3.7 \pm 1.0$ & $0.3 \pm 0.2$ \\
\hline \multirow{6}{*}{ PB pH 7.2 Stage-2 } & 4 & $7.6 \pm 0.3$ & $0.5 \pm 0.2$ & $5.9 \pm 1.0$ & $1.0 \pm 0.4$ & $3.5 \pm 0.2$ & $1.7 \pm 1.2$ & $6.4 \pm 0.3$ \\
\hline & 5 & $23.5 \pm 2.0$ & $1.8 \pm 0.5$ & $21.5 \pm 1.9$ & $1.2 \pm 0.4$ & $15.8 \pm 0.9$ & $15.6 \pm 2.5$ & $17.4 \pm 1.1$ \\
\hline & 6 & $62.0 \pm 4.1$ & $9.6 \pm 2.1$ & $51.8 \pm 8.1$ & $5.2 \pm 0.7$ & $40.3 \pm 1.5$ & $52.4 \pm 4.9$ & $41.3 \pm 3.5$ \\
\hline & 7 & $95.0 \pm 2.1$ & $27.8 \pm 2.9$ & $88.1 \pm 6.6$ & $17.0 \pm 2.4$ & $74.4 \pm 0.1$ & $74.8 \pm 10.3$ & $76 \pm 5.7$ \\
\hline & 8 & $95.3 \pm 1.7$ & $54.0 \pm 4.5$ & $96.7 \pm 1.7$ & $38.4 \pm 2.7$ & $89.6 \pm 0.4$ & $93.7 \pm 6.2$ & $91.5 \pm 2.0$ \\
\hline & 9 & $93.2 \pm 1.4$ & $89.1 \pm 4.4$ & $94.1 \pm 0.9$ & $87.0 \pm 4.9$ & $94.0 \pm 2.0$ & $97.7 \pm 2.3$ & $95 \pm 0.7$ \\
\hline
\end{tabular}

(All values are expressed as mean \pm SD) 


\begin{tabular}{|c|c|c|c|c|c|c|}
\hline Responses & Sources & $\begin{array}{l}\text { Degree of } \\
\text { Freedom }\end{array}$ & $\begin{array}{l}\text { Sum of } \\
\text { Squares }\end{array}$ & Mean Square & F Ratio & Prob $>F$ \\
\hline Y1 (\% drug release after $1 \mathrm{~h}$ ) & $\begin{array}{c}\text { Model } \\
\text { Error } \\
\text { Corrected total }\end{array}$ & $\begin{array}{l}3 \\
3 \\
6\end{array}$ & $\begin{array}{l}37.570000 \\
11.270000 \\
48.840000\end{array}$ & $\begin{array}{c}12.5233 \\
3.7567\end{array}$ & 3.3336 & 0.1746 \\
\hline Y2 (\% drug release after $3 \mathrm{~h}$ ) & $\begin{array}{c}\text { Model } \\
\text { Error } \\
\text { Corrected total }\end{array}$ & $\begin{array}{l}3 \\
3 \\
6\end{array}$ & $\begin{array}{c}2511.9500 \\
358.7786 \\
2870.7286\end{array}$ & $\begin{array}{l}837.317 \\
119.593\end{array}$ & 7.0014 & 0.0721 \\
\hline Y3 (\% drug release after $6 \mathrm{~h}$ ) & $\begin{array}{c}\text { Model } \\
\text { Error } \\
\text { Corrected total }\end{array}$ & $\begin{array}{l}3 \\
3 \\
6\end{array}$ & $\begin{array}{l}33.970000 \\
40.850000 \\
74.820000\end{array}$ & $\begin{array}{l}11.3233 \\
13.6167\end{array}$ & 0.8316 & 0.5585 \\
\hline
\end{tabular}

\begin{tabular}{|c|c|c|c|c|}
\hline \multicolumn{2}{|c|}{ Table 19: Parameter Estimates after 1 $\boldsymbol{h}$ for Coated Tablets. } \\
\hline Term & Estimate & Std Error & t Ratio & Prob $>|\mathbf{t}|$ \\
\hline Intercept & 5.8 & 14.70571 & 0.39 & 0.7196 \\
\hline Prod. Temp & 0.15 & 0.484553 & 0.31 & 0.7771 \\
\hline \%t build up & -0.5 & 0.161518 & -3.10 & 0.0535 \\
\hline (Prod.temp-30)*\% Wt build up-13) & -0.045833 & 0.080759 & -0.57 & 0.6100 \\
\hline
\end{tabular}

\begin{tabular}{|c|c|c|c|c|}
\hline \multicolumn{2}{|c|}{ Table 20: Parameter Estimates after 3 $\boldsymbol{h}$ for Coated Tablets. } \\
\hline Term & Estimate & Std Error & t Ratio & Prob $>|\mathbf{t}|$ \\
\hline Intercept & 36.389286 & 82.97312 & 0.44 & 0.6906 \\
\hline Prod. Temp & 1.825 & 2.733963 & 0.67 & 0.5522 \\
\hline \% Wt build up & -4.125 & 0.911321 & -4.53 & $0.0202^{*}$ \\
\hline (Prod.temp-30)*(\% Wt build up-13) & -0.120833 & 0.45566 & -0.27 & 0.8080 \\
\hline
\end{tabular}

\begin{tabular}{|c|c|c|c|c|}
\hline \multicolumn{2}{|c|}{ Table 21: Parameter Estimates after $\mathbf{6} \boldsymbol{h}$ for Coated Tablets. } \\
\hline Term & Estimate & Std Error & t Ratio & Prob $>|\mathbf{t}|$ \\
\hline Intercept & 94.366667 & 27.99756 & 3.37 & $0.0434^{*}$ \\
\hline Prod. Temp & 0.15 & 0.922519 & 0.16 & 0.8812 \\
\hline$\%$ Wt build up & -0.466667 & 0.307506 & -1.52 & 0.2264 \\
\hline (Prod.temp-30)*\% Wt build up-13) & 0.0625 & 0.153753 & 0.41 & 0.7116 \\
\hline
\end{tabular}

1 and $3 \mathrm{~h}$ until the coating dissolve. Here, the values indicate a better fit. However, RMSE value is observed to be 1.9382, 10.936 and 3.6901.

Considering the $\mathrm{P}$ value the model was found to be insignificant $(p>0.05)$ for effect of factors selected, on drug release at the end of 1,3 and $6 \mathrm{~h}$.

The composite desirability of the final formulation, 0.810244 as shown in Figure 7, was obtained, which predicted $81 \%$ chance of getting desired response using optimized values of the factors.

Coating was performed using different process parameters and the effects of bed temperature and percentage weight build up had been shown in the various formulations (Coat $\mathrm{f} 5 \mathrm{~A}$ to Coat $\mathrm{f} 5 \mathrm{E}$ ). Lower bed temperature during coating resulted in formation of poor film leading to premature drug release, as observed in acidic stage from Coat $\mathrm{f} 5 \mathrm{C}$ in comparison to Coat $\mathrm{f5} \mathrm{A}$, in which bed temperature was higher. However, in both the batches, coating percentages were same. At higher temperature, particles of dispersion melted and hard film was formed that prevented the drug release in acidic stage. Formulations Coat f5 B and Coat f5 Having 19\% coating showed more drug retardation and increase in the lag time leading to incomplete drug release in buffer stage 2 (Table 17 and Figure 8). Coated at optimum bed temperature and percent weight build up, formulation Coat f5 Emet the pharmacopoeia specifications, as it hardly released drug in acid and phosphate buffer stage 1 , but released maximum drug in phosphate buffer stage 2. Further, the release pattern was confirmed by observing the reproducible batches.

The results of the stability studies are Table 22 . 

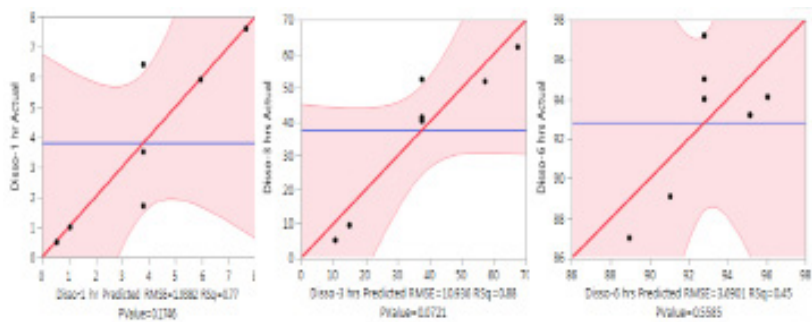

Figure 6: Dissolution Response Actual by Predictable Plots for Coated Tablets.

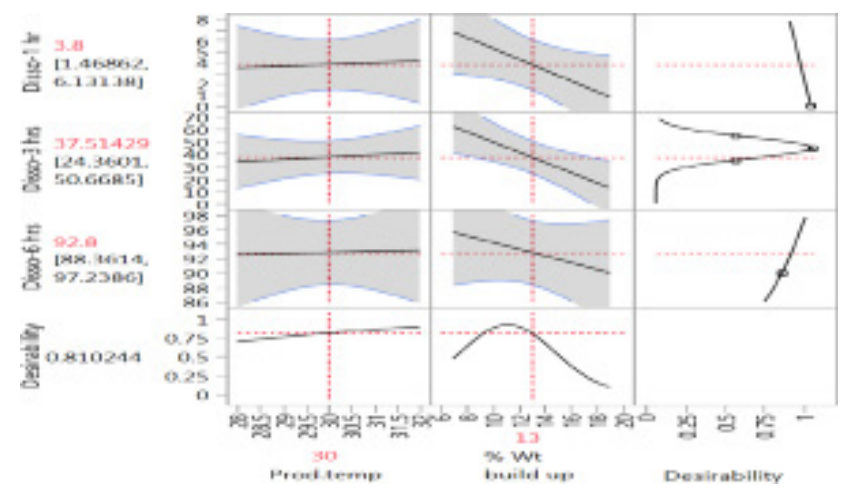

Figure 7: Prediction Profiler for Coated Tablets.

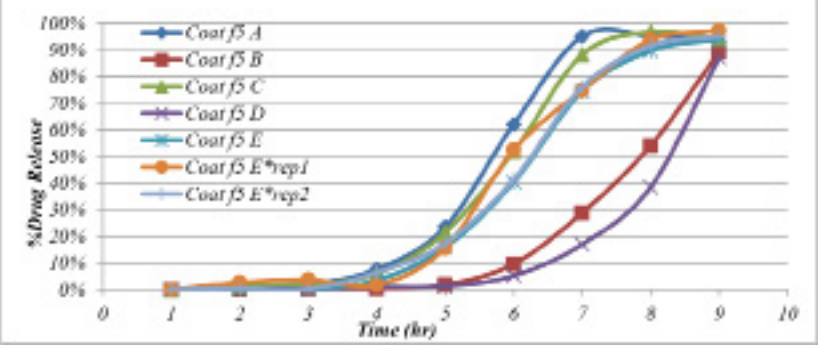

Figure 8: Effects of Process Parameters on \% Drug Release.

\begin{tabular}{|c|c|c|c|}
\hline \multirow[t]{2}{*}{ Parameter } & \multirow[t]{2}{*}{ Specifications } & \multicolumn{2}{|c|}{$\begin{array}{l}\text { Test Conditions } \\
40 \pm 2^{\circ} \mathrm{C} / 75 \pm 5 \% \mathrm{RH} \\
\text { (Accelerated) }\end{array}$} \\
\hline & & Initial & Final \\
\hline Appearance & $\begin{array}{l}\text { White plane } \\
\text { surfaces; round } \\
\text { shaped tablets }\end{array}$ & Complies & Complies \\
\hline $\begin{array}{l}\text { Thickness } \\
(\mathrm{mm})\end{array}$ & - & $3.48 \pm 0.08$ & $3.49 \pm 0.010$ \\
\hline $\begin{array}{l}\text { Hardness } \\
\quad(k p)\end{array}$ & - & $4.73 \pm 0.16$ & $5.2 \pm 0.14$ \\
\hline Weight (mg) & - & $\begin{array}{l}113.22 \\
\pm 0.50\end{array}$ & $113.54 \pm 0.41$ \\
\hline Assay (\%) & - & $98.30 \pm 1.08$ & $97.10 \pm 1.08$ \\
\hline $\begin{array}{c}\text { Dissolution } \\
(\%)\end{array}$ & - & $94.0 \pm 2.0$ & $93.0 \pm 5.0$ \\
\hline
\end{tabular}

\section{CONCLUSION}

The present investigation has been carried out with a significant plan to develop colon specific tablet of tofacitinib. $\mathrm{pH}$ and time dependent matrix tablets have been prepared using sodium CMC and Eudragit ${ }^{\circledR}$ S100 coating to prevent drug release in the upper GIT and give maximum drug release in colon. Based on the results of in vitro drug release, it has been observed that the combination of $11 \%$ sodium CMC with $20 \%$ MCC in the matrix tablets have extended the drug release up to $6 \mathrm{hr}$. The core F10 batch has been selected for the coating using $10 \% \mathrm{w} / \mathrm{w}$ solid content dispersion of Eudragit ${ }^{\circledR} \mathrm{S} 100$. Coating has been performed at $30^{\circ} \mathrm{C}$ bed temperature and 13\% weight buildup has been observed to be sufficient to get 3-4 h lag time. As per the reports in literatures, in fasting stage the arrival time for smaller tablets into the colon is about 3-4 h; thus, the current formulation meets the specification of colon targeted drug delivery. On behalf of in vitro study current formulation is suitable for colonic delivery as negligible drug release observed in acid and phosphate buffer stage- 1 followed by maximum drug release in the phosphate buffer stage 2 .

\section{ACKNOWLEDGEMENT}

The authors are thankful to Sun Pharmaceutical Industries Limited, Gurugram, India and Noida Institute of Engineering Technology, Greater Noida, Uttar Pradesh, India for providing all kind of support.

\section{CONFLICT OF INTEREST}

There is no academic, financial, personal and commercial conflict of interest among the authors.

\section{ABBREVIATIONS}

JAK: Janus kinase; STAT: Signal transducer and transcription; UC: Ulcerative colitis; FDA: Food and drug administrative; Kp: Kilopound; Sodium CMC: Sodium carboxy methylcellulose; GIT: Gastro intestinal tract; TNF: Tumor necrosis factor; HPC-L: Hydroxypropyl cellulose low substitute.

\section{REFERENCES}

1. Tran V, Shammas RM, Sauk JS, Padua D. Evaluating tofacitinib citrate in the treatment of moderate-to-severe active ulcerative colitis: Design, development and positioning of therapy. Clin Exp Gastroenterol. 2019;12:179-91.

2. Kathleen A, Jurenka JS. Inflammatory bowel disease part I: Ulcerative colitis-pathophysiology and conventional and alternative treatment options. Altern Med Rev. 2003;8(3):247-83. 
3. Sharma M, Joshi B, Bansal M, Goswami M. Formulation and evaluation of colon targeted tablets of mesalazine. Journal of Drug Delivery and Therapeutics. 2012;2(5):24-36.

4. Ekbom A, Helmick C, Zack M, Adami HO. Ulcerative colitis and colorectal cancer: A population-based study. N Engl J Med. 1990;323(18):1228-33.

5. Amidon S, Brown JE, Dave VS. Colon-targeted oral drug delivery systems: Design trends and approaches. AAPS Pharm Sci Tech. 2015;16(4):731-41.

6. Bansode AS, Athare AB, Kasture VS, Kendre PN. Colon targeted drug delivery system: An overview. International Imperial Journal of Pharmaceutical and Cosmetology. 2012;2(2):1-7.

7. Patel JK, Patel NV, Shah SH. Formulation and in-vitro evaluation of mesalamine matrix tablets using chitosan for colonic drug delivery. J Pharm Res. 2009;2(7):1319-23.

8. Sager K, Dattatray A, Dhanjay L. Formulation and evaluation of colon targeted marix tablet of azathioprine. Indo American Journal of Pharmaceutical Research. 2019;9(7):1-6.

9. Beattie DT, Pulido-Rios MT, Shen F, Ho M, Situ E, Tsuruda PR, et al. Intestinally-restricted Janus Kinase inhibition: A potential approach to maximize the therapeutic index in inflammatory bowel disease therapy. Journal of Inflammation. 2017;14(1):1-1.

10. Weisshof R, Golan MA, Yvellez OV, Rubin DT. The use of tofacitinib in the treatment of inflammatory bowel disease. Immunotherapy. 2018;10(10):837-49.

11. Nielsen $\mathrm{OH}$. New strategies for treatment of inflammatory bowel disease. Front Med. 2014;1:1-5

12. Sandborn WJ, Ghosh S, Panes J, Vranic I, Su C, Rousell S, et al. Tofacitinib, an oral Janus kinase inhibitor, in active ulcerative colitis. N Engl J Med. 2012;367(7):616-24.

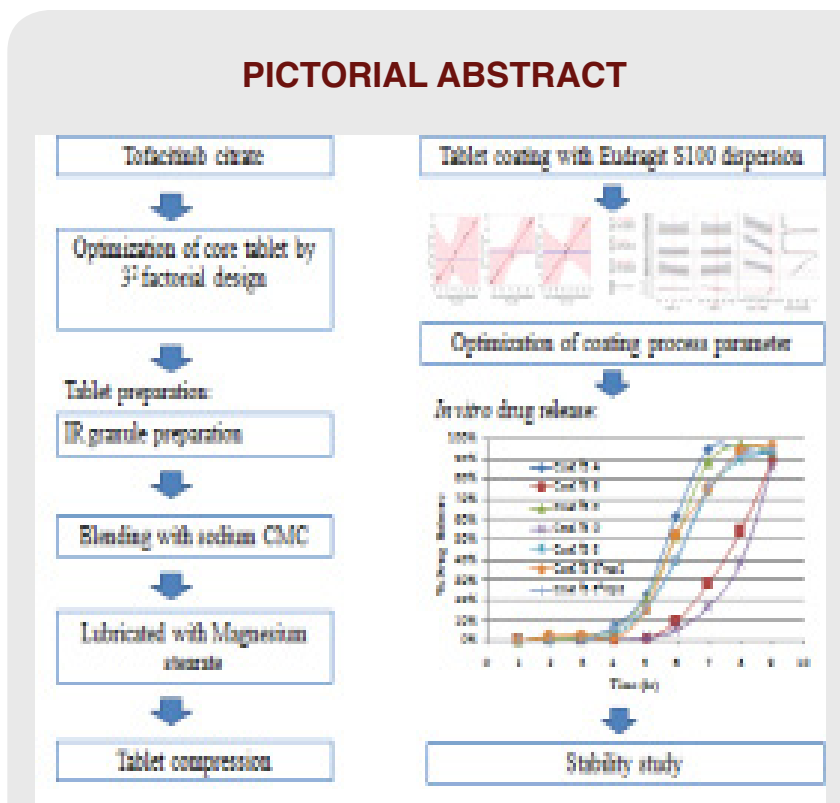

13. Feagan B. Update on tofacitinib for inflammatory bowel disease. Gastroenterology and Hematology. 2016;12(9):572-4.

14. Thakariya NV, Ezhava SB. Development and validation of UV Spectrophotometric method for the estimation of tofacitinib citrate. Pharma Science Monitor. 2017;8(2):401-8.

15. Dangi AA, Divya J. Formulation and evaluation of colon targeted drug delivery system of levetiracetam using pectin as polymeric carrier. J Appl Pharm Sci. 2013;3(1):78-87.

16. Arunachalam A, Mazumder A. The outcome of formulation and in vitro release studies of levothyroxine sodium tablets. Asian Journal of Pharmaceutical Science and Technology. 2011;1(1):33-9.

17. Chavan H, Chhabra G, Gujarathi N, Jadhav A. Comparative study of In-process and finished products quality control test for tablet and capsules according to pharmacopoeias. Asian Journal of Pharmaceutical Research and Development. 2018;6(3):60-8.

18. Saleem M, Shahin M, Srinivas B, Begum A. Evaluation of tablets by friability apparatus. Int J Res Pharm Chem. 2014;4(4):837-40.

19. Ratnakumari T, Chetty CM, Reddy DRP. Formulation and evaluation of aceclofenac matrix tablets for colon drug delivery. J Global Trends Pharmaceut Sci. 2010;1(1):53-60.

20. Tenjarla S. Dissolution of commercially available mesalamine formulations at various pH levels. Drugs in R and D. 2015;15(2):211-5.

21. Rençber SE, Senyigit Z, Ozyazici M. Stability studies of compression coated ornidazole tablets for colon specific drug delivery. Journal of Research in Pharmacy. 2019;23(1):34-43.
Tofacitinib, the pan-Janus kinase (JAK) inhibitor, had been approved by FDA for its use in the treatment of moderate to severe ulcerative colitis, in 2018. The present work aimed to develop a new colon targeted drug delivery system for tofacitinib using combined approaches of formulating an extended release matrix tablet by wet granulation method, along with a $\mathrm{pH}$ sensitive polymer coating of Eudragit ${ }^{\circledR} \mathrm{S} 100$. Formulation variables used in the latter, were optimized. Negligible drug release was obtained in $0.1 \mathrm{~N} \mathrm{HCl}$ and $6.4 \mathrm{pH}$ phosphate buffer media, where as in $7.2 \mathrm{pH}$ phosphate buffer medium, the drug release increased up to $94.2 \pm 2.0 \%$. The minimum concentration of sodium carboxymethyl cellulose (CMC) for 6 hour's extended release of drug from the matrix tablet, was observed to be $11 \%(\mathrm{w} / \mathrm{w})$ and $13 \%$ was the minimum functional coating percentage for obtaining an adequate lag time. Thus it was found from the study, that the lag time of the drug release was highly affected by the coating percentage of Eudragit S 100 and product temperature during coating. The rate of drug release was found to be depended on the concentrations of sodium CMC used in the core tablet. Finally, the optimized product was found to be stable over three months of storage at $40 \pm 2{ }^{\circ} \mathrm{C} / 75 \pm 5 \% \mathrm{RH}$. 


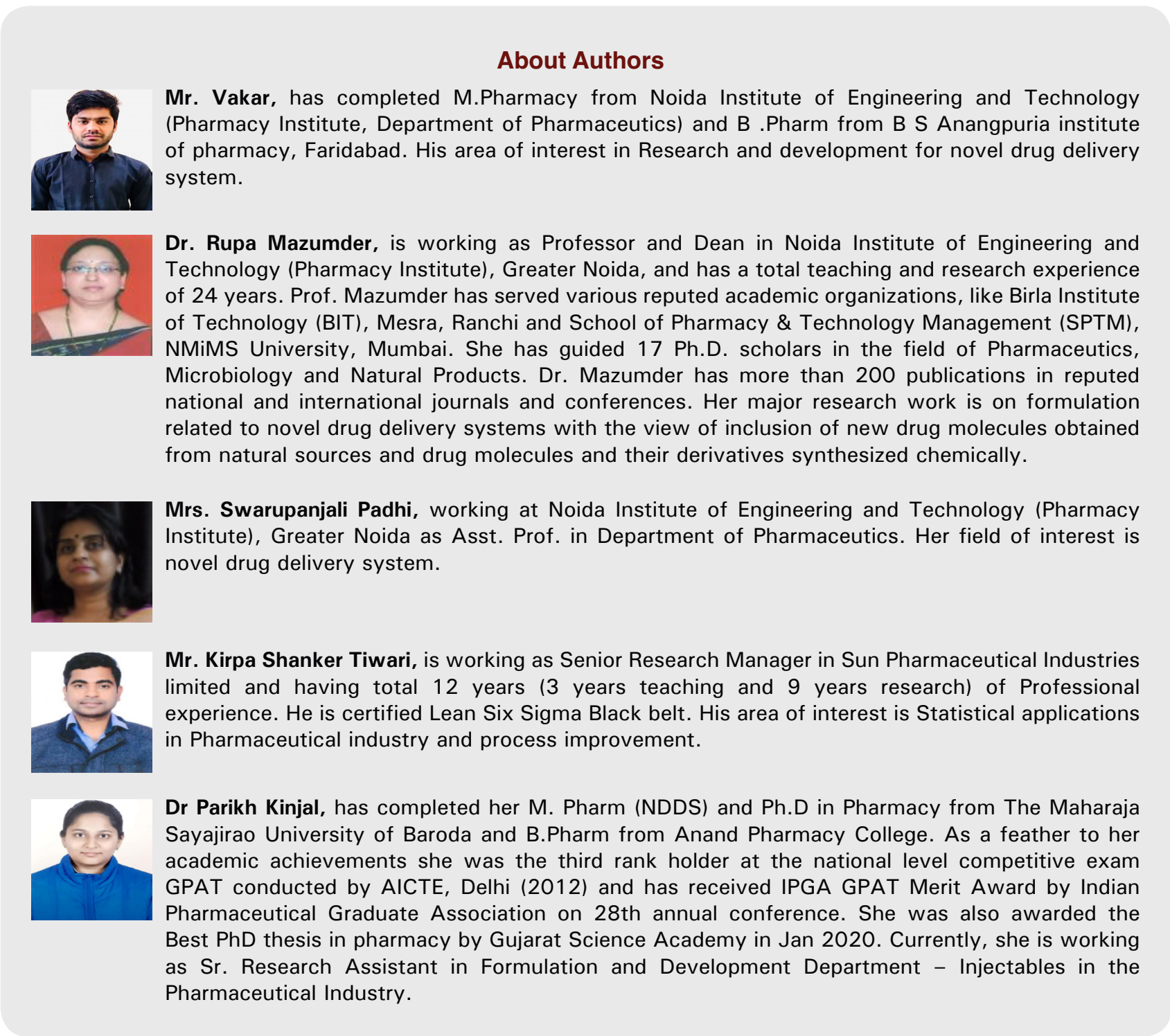

Cite this article: Vakar, Mazumder R, Padhi S, Tiwari KS, Kinjal P. Development of Colon Targeting Tablet of a JAK Inhibitor to Combat Chronic Ulcerative Colitis: A Novel Approach for Local Drug Delivery. Indian J of Pharmaceutical Education and Research. 2021;55(2s):s414-s427. 